\title{
Impact of Work-Life Balance, Happiness at Work, on Employee Performance
}

\author{
Khaled adnan Bataineh ${ }^{1}$ \\ ${ }^{1}$ Business Administration Department, Faculty of Administrative Science and Finance, Irbid National University, \\ Jordan
}

Correspondence: Khaled adnan Bataineh, Business Administration Department, Faculty of Administrative Science and Finance, Irbid National University, Jordan.

Received: November 13, 2018

Accepted: January 10, $2019 \quad$ Online Published: January 17, 2019

doi:10.5539/ibr.v12n2p99

URL: https://doi.org/10.5539/ibr.v12n2p99

\begin{abstract}
The purpose of this research is to investigate the Relation of work-life balance, happiness, and employee performance, Accordingly, a questionnaire-based survey was designed to test the aforementioned model based on dataset of 289 employees' from the ( Med Pharma), Pharmaceutical industries in Jordan, Multiple regression was conducted to examined the research hypotheses. The results indicated that work-life balance and happiness positively and significantly affect employee performance. However, job satisfaction non-impact in employee performance. The results have enormous implication for the Pharmaceutical industries sector in Jordan.
\end{abstract}

Keywords: work-life balance, happiness at work, on employee performance, Med Pharma), Pharmaceutical industries in Jordan

\section{Introduction}

The line between work and life has been the subject of interest amongst scholars and practitioners nowadays. Several factors have been found to have sparked this interest and these include changes of demographic composition in the labor market and in the amount and pace of work, and increases in work hours (Helmle et al., 2014), A person can live a life that is happy, healthy and successful when there is work-life Balance. Work-life Balance has indeed become a primary concern to those wishing to have good quality of life ( Breitenecker and Shah, 2018) The notion of Work-life Balance has been described by many, and for the majority, work encompasses the venue of official tasks to be accomplished by individual while executing a given job. Accordingly, life encompasses a collection of activities not related to work for instance household chores and childcare. In this regard, balance is achieved when there is harmony between work and life. (Semlali and Hassi, 2016) Since the last decades, the concept of Work-life Balance has been viewed as crucial to both organizations and people, and it has indeed been found to greatly contribute in the improvement of productivity of employees which in turn impacts the performance of organizations in positive manner (Guthrie, 2012). Effective policy of work-life balance embraced by the organization allows the employees to socialize with the community while assuring that cost and turnover are under control and productivity is improved (Helmle et al., 2014).

It is yet to be affirmed when it comes to the association between the happiness of worker and productivity in the workplace. Still, the common consensus is that a happy employee will become a productive employee (Joo and Lee, 2017, Abualoush et al., 2017). For human resource management, to keep employees healthy and able to work long hours efficiently is a great challenge. One indicator of good mental health is engaging the employees at work (Nielsen et al., 2008) The well-being of employee, both physical and mental, is very important, and as stressed in studies, employee well-being impacts the success of organization. For instance, it has been reported that employees who feel good and deal with less stress at work and at home are more likely to experience satisfaction towards their work, and this can significantly affect their well-being and also their organization. (Koubova and Buchko, 2013), Even though the factors of engaging at work, career satisfaction, and subjective well-being are showing judicious relationships with each other while also demonstrating inclination towards showing consistency within individuals over time, among scholars and practitioners, employee engagement is their major concern. This owes to the fact that engaged workers appear to have greater level of motivation, and demonstrate greater level of involvement in their jobs and organizations (Shaffer et al., 2016). These employees are also more productive, and have greater level of readiness in giving more than what they are supposed to in 
contributing to the survival and success of their organization (Shaffer et al., 2016, Obeidat et al., 2018).

Work-life balance and happiness is still insufficiently studied although this subject has been receiving increasing attention from scholars. Relevantly, employees spend significant amount of their time working. Still, past studies on life satisfaction or well-being were focusing on non-work populations (e.g., patients, children, students, and/or adolescents). As such, this study is of the view that in the domain of management, the lack of attention on employee well-being has become a critical gap in the extant research. Meanwhile, the negative behavior demonstrated by employee can be triggered by the increase of work stress (Emslie and Hunt, 2009). In reality, as reported by Mullen and Kelloway (2010), failure in performing tasks, turnover, and absenteeism are now becoming common in the workplace, and all these are compromising the effectiveness and development of the organization. It is the obligation of the organization to play a major role in attaining and sustaining employees that are healthy, well-trained, and capable on a long-term basis (Nielsen et al., 2008). Further the purpose, organization needs to delineate an environment in which employees can grow themselves and discern the well-being (Nielsen et al., 2008). Employees are obliged demonstrate hard work and in the course, they often have to work extra hours so that they could fulfill their financial obligations, which leads to a disparity between work and family. Long working hours cause job-to-home spillover to increase and this may impact negatively on job performance of employees and productivity and profits of organizations. This implies the presence of gap which this study attempts to Fill gaps in previous studies , particularly in terms of happiness of employees and attention to their family in order to increase creativity and innovation in terms of performance (of the employees).

This study therefore attempts to understand the effect of Work-life balance and Happiness at work on employee's performance and hence, the following questions will be addressed in this study:

1. Does Work-life balance impact employee performance?

2. Does Happiness at work (employee engagement, job satisfaction, and affective organizational commitment) impact employee performance?

\section{Literature Reviews}

\subsection{Work-Life Balance}

It wasn't until the mid-60s that the subject of work-life balance became the subject of interest among scholars. For instance, Kahn et al. (1964) concluded that for employees, work-family conflicts are a substantial stress source. Relevantly, the notion of equilibrium between family and professional life (work-family balance) is recently employed when referring to the successful development of both domains. At present time, in order to fine-tune the organizational structures to the needs of the employees or to respond to government regulations with respect to gender equality, integration, and protection of families, a lot of organizations dedicate their resources to the initiatives of work-life (Susana and Ramón 2013). As has been emphasized by a number of scholars, at present time, it is likely to have employees that demand the initiatives of work-life balance from the organization. Such demand has been closely linked to the increasing commonness of dual-career couples, family or dependent accountabilities, or the wish to devote more time to friends or enjoy leisure undertakings (Lavoie, 2004).

In studies on work-life, the focal point has been the effect of organizational services and policies that are established for providing assistance to employees regarding the conflicts that occur between their work and their life. Accordingly, the extant literature attempted to comprehend the role played by organizations to help reduce the conflict experienced by the employees that occurs from the demands of work and the role they are obliged to play at home(Emslie, and Hunt, 2009; Hon and Chan, 2013). As evidenced from the findings, employees with access to services including flexible schedules, childcare, parental leave, and support from supervisor appear to be more likely have less conflicting work-life, greater job satisfaction, less stress, and are less inclined to want to quit (Helmle et al., 2014). In research on the issue regarding work-life, gender has also been explored, particularly with respect to how the roles and expectations of gender impact the perceptions regarding work and family roles. Here, as evidenced by the findings, in certain situation, gender expectations in a situation impact how far individuals feel incompatibility between work and life roles, and this can cause the perceived level of stress and the perceptions of conflict between the roles of work and life to increase (Helmle et al., 2014; Lawson et al., 2013).

The management of work-life balance and/or work-family conflict interest of employees have been found to be among the primary aspects to be addressed by the organization as a way to preserve human resources (Au and Ahmed, 2014). Work-life balance encompasses a balance between two entirely separate roles performed by a 
person namely the roles of work and the roles of family, and to holder of the roles, both bring satisfaction (Shaffer et al., 2016).

The benefits of work-life can improve both the life quality of employees and the effectiveness of the organization. Hence, there appears to be countless delineations regarding work-life balance, but all appear to be in agreement that work encompasses a group of formal tasks completed by an individual while occupying a given job. Life comprises a group of activities not associated with work such as household chores, care of elderlies and care of children (Anwar et al., 2013), Emslie and Hunt (2009) stated that balance is attained when the domain of work and that of life are in harmony. Work-life balance is about a person's capacity irrespective of age or gender in successfully combining work and household accountabilities. Within this context, work becomes a term that can be regarded as paid employment and also free work done for an employer.

Conversely, the notion of "life" is not related to work and it can be broken down into free time used in doing leisure activities, and family time (Lawson et al.,2013). Accordingly, the concept of work-life balance defines the amount of time available to an employee in balancing between family and the demands of work. Work-life balance encompasses an employee's time-sharing ratio between work and family. When there is imbalance between work and family, whether too much on work or too much on family matters, stress and negative work attitudes can occur and these can lead to burnout (lawson et al.,2013 ). In the work of Grzywacz and Carlson (2007), work-life balance is described as the achievement of role-related expectations exchanged and shared between people and their role-related partners in the arena of work and family. Meanwhile, work-life balance was addressed by Greenhaus and Allen (2010) as the degree to which the effectiveness and satisfaction experienced by a person in terms of his work and family roles are attuned to his role priorities of life at certain point in time.

Effective Work-Life Balance is underpinned by two applicable primary concepts namely the day-to-day accomplishment and enjoyment. Achievement is the successful completion of something particularly after a series of diligent attempts or being given what is desired. With respect to the notion of enjoyment, it does not denote happiness. Rather, it denotes pride, satisfaction, celebration, joys of living as well as a sense of wellbeing. In life, achievement and enjoyment have close linkage in terms of value. In other words, a person has to have both. This is the reason why those who are deemed successful do not feel happy or are not as happy as they are supposed to be (Hon and Chan, 2013).

\subsection{Happiness at Work}

Human Resource Management (HRM) and performance is related in a manner that is one sided, and the relationship of these two does not take into account the human side of HR. For HRM, its primary resource encompasses the human factor. Somehow, in many studies in this domain, the effect of HR systems on the quality of working lives as well as the well-being of employees has not been explored. Here. Having the awareness of how different conditions of working impact human resources has become the actual challenge. However, the impact of various variables on employee attitudes is now a subject of interest amongst scholars. (Gupta, 2012),

In general, happiness relates to how people experience and appraise their lives in total. Considering that a significant amount of time of most people is spent on working, having the understanding of the role played by employment and the workplace play is highly critical. This is because such understanding can assist in the creation of happiness for individuals and communities globally. As evidenced by recent studies, work and employment drive happiness which in turn can assist in shaping the outcomes of job market, productivity, and performance of firm as well (Field and Buitendach, 2011). In academic studies, the importance of life quality within the workplace has been dubbed as a major element. In this study, happiness becomes a basic state to be achieved by nearly everyone. Among the notable past studies are the ones that examine how happiness in day-to-day work becomes attainable through better management of work atmosphere (Salas-Vallina, 2017).

Happiness at Work is more than the possession of sense of pleasure, positive affective experience, good feelings and enjoyment because it also means having meaningful work life. Furthermore, a person is deemed as a happy person when he or she feels positive emotions repetitively. A person possessing positive emotions means that he or she has good life with no readily visible threats (Saenghiran, 2014). In a study performed by Edmunds and Pryce-Jones (2008), Happiness at Work is viewed as sensibly using the accessible resources to handle challenges faced in a judicious manner. Through the active appreciation of the highs and management of the lows, the performance of individual could be maximized easier, and the potential of the individual could also be achieved. In turn, the happiness of a person and also of others can be established. In another study, the concept of Happiness at Work was described as the enjoyment of pleasant working relationship and career development, 
and also the enjoyment of the feeling of being valued and treated well (Edmunds and Pryce-Jones, 2008).

A number of concepts including the concepts of engagement (Schaufeli and Bakker 2004) and well-being (Hills $\&$ Argyle, 2001) are now deemed as forms of happiness. As shown in the extant literature, interest in the subject of happiness at work has been increasing amongst scholars (Salas-Vallina et al., 2017). For instance, Fisher (2010) reported Happiness at Work (HAW) as happy feelings towards the job itself, the characteristics embraced by the job, as well as that of the organization all together. Furthermore, HAW is described as an all-embracing construct that carries the traits "job satisfaction" and "organizational commitment." Meanwhile, the concept of Job satisfaction has been elaborated as a pleasant or positive emotional state caused by an appraisal of job or job experiences of a given individual (Huang et al.,2016)

Organizational commitment comprises a number of elements. These elements include the sense of affective devotion towards the organization, loyalty towards to the organization, and identification of the goals and values established by the organization (Field and Buitendach, 2011). In the works of Joo and Lee (2017), employee engagement and career satisfaction were found to be the two primary elements of happiness at work. In the work by Salas-Vallina et al. (2017), engagement, job satisfaction and affective organizational commitment were reported as the major constituents of HAW. In the extant past works, three main components have been the focal points, and they are employee engagement, job satisfaction, and affective organizational commitment. These components are as discussed below:

\subsubsection{Employee Engagement}

Engagement is the attachment of members of organization to the roles of work assigned to them, and in engagement, people physically, cognitively and emotionally make use of and articulate themselves during role performances (Abdallah et al., 2017). Engagement can likewise be described as an unrelenting and positive affective-motivational state of accomplishment (Field and Buitendach, 2011). For Schaufeli and Bakker (2004), work engagement is highlighted as a positive, gratifying and job linked mind state characterized by three dimensions namely dedication, absorption and vigor. Past studies on work engagement of employee found that employees who are engaged are likely to demonstrate positive organizational outcomes such as lower turnover intention, greater customer satisfaction, and greater level of productivity and profit (Joo and Lee, 2017). Engagement is also seen as a positive effect that has relation with the job and the environment of work, and as noted by Fisher (2010), engagement connotes or overtly denotes sense of persistence, alertness, energy, vigor, dedication, absorption, enthusiasm, as well as pride.

\subsubsection{Job Satisfaction}

Job satisfaction is the main priority for all organizations in establishing their policy (Yücel, 2012, ), and as a concept that has linkage to the humanitarian and utilitarian viewpoints, it is worth the scrutiny. The humanitarian viewpoint is postulates that employee satisfaction level is linked to the degree to which employees are receiving fair and apposite treatment in the organization (Abdallah et al ,2017), whereas the utilitarian viewpoint indicated that employee satisfaction contributes to behaviors impacting the operation of the organization (Yücel, 2012). Job satisfaction is also viewed as a quantifiable depiction of an emotion related response towards certain job; in other words, the person performing the job feels satisfied with it (Al-dalahmeh et al., 2018; Anitha, 2014). Likewise, job satisfaction relates to how people feel about their jobs and about the differing aspects of their jobs. Meanwhile, in a study, job satisfaction was described as the extent to which employees are fond of their work (Parvin and Kabir, 2011).

\subsubsection{Affective Organizational Commitment}

Affective organizational commitment encompasses emotional attachment felt by employee in addition to their identification with and participation in their organization and its goals (López-Cabarcos et al, 2015). It encompasses a bond established by employees within the organization and there has been strong linkage between affective organizational commitment and positive work-related behaviors (e.g., dedication and loyalty) (Obeidat et al 2014; Schoemmel and Jønsson 2014), Affective organizational commitment is also describable as the association of a person with an organization, his/her belief in the goals established by the organization, and working to achieve those goals by being part of that organization (Ammari et al 2017, Abdallah et al 2017). Relevantly, affective organizational commitment has been viewed as a force uniting a person to action that relates to one or more targets(Enache et al.,2013), This term has been used in defining organizational commitment whereby three characteristics are involved as follows: a solid conviction and acceptance towards goals and values of the organization; readiness to make significant effort on behalf of the organization; and a strong wish remain as part of the organization (Gyensare et al., 2017). 


\section{Employee Performance}

Employee Performance can be described as responses in the form of behaviors reflecting what has been learned by the employee or the kind of training that the employee has received; it encompasses the outcome of the mental and psychological capabilities (Faiza and Nazir, 2015). Employee Performance is a concept that is increasingly popular amongst scholars of management sciences, as employee performance is vital to both individual and the organization. Employee Performance contributes to the overall betterment of the processes of the organization particularly in terms of efficiency and productivity (Abualoush et al., 2018a). Employee performance has linkage to the activities and tasks employees carry out in effective and efficient manner, and it also dictates how much employees contribute to the organization and among the contributions of employees are output quantity, work attendance, and accommodating attitude (Abualoush et al., 2018b). Furthermore, the financial or non-financial outcomes of the employee which are closely related to the performance and success of the organization is also reflected by employee performance (Anitha, 2014).

In regards to the notion of performance, it is measurable using different mechanisms (Faiza and Nazir, 2015), and in general, performance encompasses what is done or not done by employee. It entails the full outcome or success of a person during specific periods of duty as opposed to the predetermined and established standard of work and targets or criteria (Abualoush et al., 2018; Pawirosumarto et al., 2017). Performance is the product of the capacity of employee, multiplied with support and effort. Hence, reduction or nonexistence of one factor will cause decrease in performance (Pawirosumaro et al., 2017 ).

\section{Work-Life Balance, Happiness at Work and Employee Performance}

\subsection{Work-Life Balance and Employee Performance}

In the era of knowledge, different skill sets and requirements are needed from employees, as opposed to those required during the era of industry. Correspondingly, within organizations, work health is deemed to be a resource, and as emphasized by researchers, for management, the promotion of employee's health should be made as the organization's vital part (Guthrie, 2012). However, considering the limitation of resources, the issue is on how an individual could manage to have satisfactory personal life while also delivering excellent results at work, The emerging question is on whether both goals are contradictory or complementary to one another (Koubova and Buchko, 2013). Inability to attain the correct balance with respect to effort and reward has significant linkage to the dearth of control over workload as well as lack of energy in fulfilling personal needs and obligation. When there is imbalance between effort and reward, fatigue, poor performance and declined life quality can result (Johari et al., 2018). Among scholars, there are generally three primary concerns pertaining work-life imbalance considering that it is impacted by technological influence. The first concern is on the developments at work which can be a hazard the work life balance, while the second concern is on the shifting nature of work activities particularly tasks that are associated with technology which requires updated knowledge of the field, and the third concern is regarding the shifting work demands. (Helmle et al., 2014)

There have been a lot of explanations regarding work life balance and the notion would have different meaning to different individuals with generational differences which greatly contribute to these differing perspectives. As evidenced by a number of works, younger employees are likely stress on work life balance because they do not desire having the demands of work impacting their lifestyles. Nonetheless, younger and older workers both want flexibility in terms of schedules and arrangements. It is just unfortunate that some supervisors are unwilling to employ flexible arrangements, due to unpredictability and potential abuse of these methods (Hon and Chan, 2013; Susana and Ramón, 2013)

Work-life balance implicates the attitudes, behaviors and wellbeing of employees as well as the effectiveness of the organization (Au and Ahmed, 2014). Hence, companies are obliged to integrate new management practices that provide social and supervisory support. The perceptions of superiors towards their employee work-life conflict also greatly dictate the career progress of employees (Au and Ahmed, 2014). In the last few years, the issue of work-life balance has been heavily scrutinized particularly in terms of increasing the flexibility of paid work and improvements in working conditions. Within the industry of hospitality, physical and emotional stresses have been reported to cause the lack of work life balance. The testing of the impacts of these variables (physical and emotional stresses) on what is embedded on the job and job performance includes the examination of work overload and work life balance. In this regard, employees with heavy workloads were reported to have low work life balance, were less likely to be embedded within their jobs while also demonstrating poor job performance. Relevantly, stress is also a dimension of personal employee similar to emotional exhaustion, and among hotel employees, stress has been reported to affect their quality of life (Lawson et al., 2013). Additionally for hotel employees, the spillover of stress has been viewed to exacerbate the stress on work life balance. (Hon and Chan 2013) 
It is possible for employees to leave their work if their failure in integrating work and network roles becomes intolerable. The withdrawal may be in a form of absenteeism, below optimum level performance, or they can leave the organization for good. Such phenomenon accentuates the prominence of sustainable HRM practices because such practices will maximize profits while also minimizing the detriment to employees and their families, as well as communities. (Lawson et al., 2013; Gupta, 2012)

In the context of organizations and people, work life balance has demonstrated its significance since the past decades. Work life balance has indeed been found to be the major factor in the productivity improvement of employees and this has a positive impact on the general performance of organizations (Semlali and Hassi, 2016). An organization needs to implement effective work-life balance policy, that is, a policy that allows employees to remain socially connected with society while cost and turnover are controlled, and productivity improved (Helmle et al., 2014).

\subsection{Happiness at Work and Employee Performance}

The latest studies reported that employees who are happy appear to be more involved in work roles while enjoying greater level of job satisfaction. As reported by American Psychological Association (2014), employers advocate the significance of making employees happy, and in fact, these employers are intensifying their efforts for the sake of their employees' happiness. Correspondingly, in the context of Taiwan, the current annual survey Taiwan by Common Wealth and Cheers magazines also mentioned making employees happy as the primary factor that has led to the recognition of the best employer (Gupta, 2012). Amongst practitioners and scholars, their main concern is employee's engagement owing to the fact that engaged workers appear to have greater level of motivation while demonstrating more involvement in their jobs and organizations, and showing greater level of productivity and readiness to go beyond expectation in assisting the survival and growth of their organizations (Joo and Lee, 2017, Vincent- Höper et al., 2012).

As reported by a lot of studies, happy employees are inclined to show greater level of productivity, produce fresh ideas and attempt to accomplish similar job use different groundbreaking methods to improve effectiveness and reduce the time spent (Saenghiran, 2014)

Furthermore, among the desirable effects to be anticipated from having affectively committed employees are: better professional endeavor and performance, positive employee outcomes and behaviors, and innovative behavior demonstrated by employees (López-Cabarcos et al., 2015). Furthermore, review of the extant literature is demonstrating that having strong affective commitment towards the organization makes employees work harder at their jobs and show better performance as opposed to those that have less affective commitment (Ammari et al 2017; Abdallah et al 2017).

\section{Research Methodology}

\subsection{Research Model}

This study presents a theoretical model based upon the review of literature. The model can be viewed in Figure 1 . As shown by the model, the independent variables are Work-life balance and Happiness at work, while the dependent variable is employee performance. The model shows the conjectured relationship between the independent variables and the dependent variable.

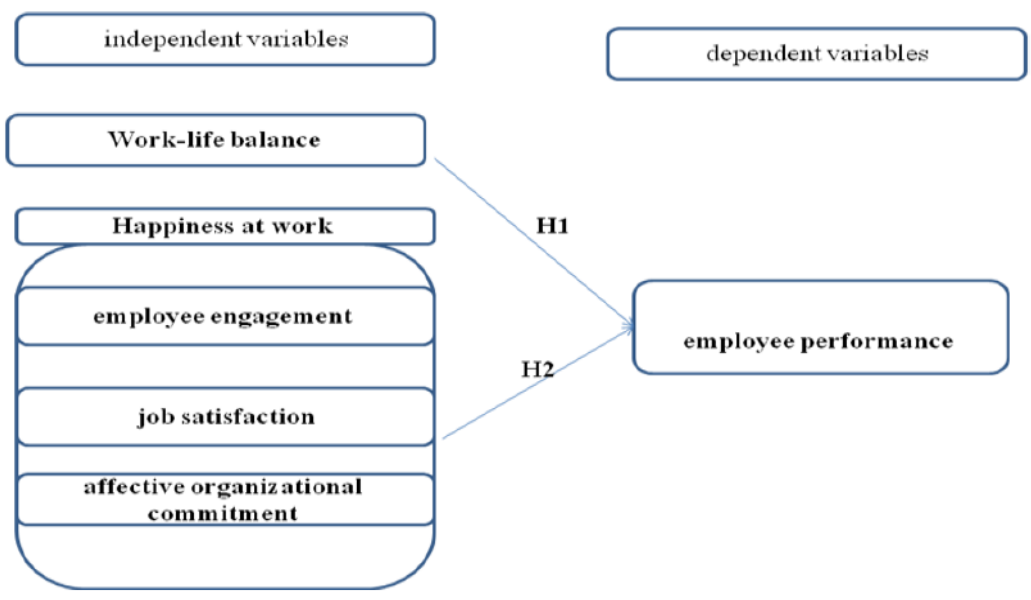

Figure 1. Research Model 


\subsection{Research Hypotheses}

As indicated earlier, this paper is examining the effect of Work-life balance and Happiness at work on employee performance, and therefore, the hypotheses below are to be tested in this paper:

H1: There is a statistically significant effect of Work-life balance on employee performance.

H2: There is a statistically significant effect of Happiness at work (employee engagement, job satisfaction, and affective organizational commitment) on employee performance.

\subsection{Measurement}

This study measures the effect of Work-life balance and Happiness at work alongside its dimensions (employee engagement, job satisfaction and affective organizational commitment) on employee performance, specifically at Med Pharma,. In gathering the information, the instruments used in this study include past works, books, references, as well as periodicals; these are the secondary sources. Meanwhile, the questionnaire has been chosen as the primary source of data gathering. The questionnaire that this study uses for data gathering was based upon the extant literature. The responses on each item (related to the variables) are provided by the participants using the five Point Likert-scale where " 1 " means "strongly disagree", "2" means "disagree", "3" means "neutral", "4" means agree, and "5" means "strongly agree".

The questionnaire used in this study contains 3 parts, whereby the first part covers items related to the demographic information of the respondents, particularly on their gender, education level, position and years of experience. Meanwhile, the remaining 2 parts relate to the variables, namely the independent variables (IV) and the dependent variable (DV). In particular, the second part encompasses items constructed to measure the dimensions of the independent variables whereby the third part includes items which measure the dimensions of the dependent variables. The questionnaire attempts to secure information regarding the direct impact of IV on DV. Overall, there are 28 items in the questionnaire selected following a broad review of the applicable literature (Work-life balance, Happiness at work, employee performance), and these items measure the model constructs. Accordingly, in order that the selected items are appropriate with this study's context, minor amendments were made to these items. The items on Work-life balance are based on Helmle et al2014; Johari et al 2018, while items on Happiness at work alongside its dimensions (employee engagement, job satisfaction, and affective organizational commitment) are adaptations from Al-dalahmeh et al. (2018) and Bisharat et al. (2017). Meanwhile, items on employee performance which is this study's dependent variable are based on Abualoush et al. (2018).

\subsection{Population and Sample}

The population chosen in this study comprises everyone employed at Middle East Pharmaceutical \& Chemical Ind. \& Med. Appliances (Med Pharma), Pharmaceutical industries. A total of 315 employees who represent all company staffs were sought after to participate in the survey and at the end, 283 respondents returned usable questionnaire, which accounts to $89 \%$ rate of return.

\subsection{Respondents Demographic Profile}

Through demographic data, the key attributes of the respondents can be determined, and among the key attributes include education, gender, position, and years of experience, all of which, are basic information of the respondents. The key attributes of the respondents in (Med Pharma) are presented in Table (1).

Table 1. Demographic data for respondents

\begin{tabular}{ccc}
\hline Category & Frequency & Percentage \% \\
\hline Gender & 195 & $69 \%$ \\
Male & 88 & $31 \%$ \\
Female & 258 & $91.3 \%$ \\
Education & 22 & $7.7 \%$ \\
Bachelor's Degree & 3 & $1 \%$ \\
Masters Degree & & $38 \%$ \\
PhD & 108 & $45.1 \%$ \\
\hline Experience & 128 & $12.7 \%$ \\
Less than 5 years & 34 & $4.2 \%$ \\
5 - Less than 10 years & 13 & $82.7 \%$ \\
10 - Less than 15 years & & $14.2 . \%$ \\
15 years and above & 234 & $3,1 \%$ \\
\hline Position & 40 & \\
\hline Lower management & 9 & \\
Middle management & & \\
Top management & & \\
\hline
\end{tabular}




\subsection{Reliability and Validity}

A group of experts with the know-how in the design of the administrative sciences' questionnaires were invited to evaluate the questionnaire. Hence, members from the information systems and business administration departments of the Jordanian University evaluated the questionnaire. These members were chosen due to their expansive experience and therefore, they have the credibility in validating the questionnaire items. These experts also made suggestions and recommendations on certain items and accordingly, amendments were made before the questionnaire was distributed.

Authenticated analysis is associated with the degree of consistency evaluation between various variable measurements. In this regard, the coefficient of Cronbach's Alpha is used to determine the reliability of the variables in all dimensions. Bagozzi and Yi (1988) are among those who suggested the values of all variable or dimensional scales to be greater than the commended value of 0.60 . In this study, for all the tested variables, the Cronbach's alpha coefficients were greater than 0.60 and this demonstrates the reliability of the compound measure. The Cronbach's alpha coefficient values were acceptable (between 0.821 and 0.875), and this demonstrates reliability of the compound measure. Table (2) presents the details.

Table 2. Cronbach's Alpha for all the variables

\begin{tabular}{ccc}
\hline Variables & Number of items & Cronbach's Alpha \\
\hline Work-life balance & 8 & 0.834 \\
Employee engagement & 4 & 0.856 \\
Job satisfaction & 4 & 0.853 \\
Affective organizational commitment & 4 & 0.821 \\
Employee performance & 8 & 0.875 \\
\hline
\end{tabular}

\subsection{Descriptive Analysis}

The study variables are described in this section. Computation was made to determine the mean and standard deviations for each dimension of the dependent and independent variables. The mean highlights the data's central tendency while the standard deviation measures the scattering of data which presents an index of the spread or variability in the data

Table 3. Mean and standard deviation of the research's Variables

\begin{tabular}{|c|c|c|c|c|c|}
\hline $\begin{array}{l}\text { Type of } \\
\text { Variable }\end{array}$ & Variables & Mean & Standard Deviation & Level & Order \\
\hline Independent & Work-life balance & 3.84 & 0.76 & Moderate & 1 \\
\hline \multirow[t]{4}{*}{ Variables } & Happiness at work & 3.51 & 0.64 & Moderate & 4 \\
\hline & Employee engagement, & 3.54 & 0.61 & Moderate & 3 \\
\hline & Job satisfaction, & 3.52 & 0.66 & Moderate & 5 \\
\hline & $\begin{array}{l}\text { Affective organizational } \\
\text { commitment }\end{array}$ & 3.47 & 0.63 & Moderate & 6 \\
\hline $\begin{array}{r}\text { Dependent } \\
\text { Variable }\end{array}$ & Employee Performance & 3.62 & 0.73 & Moderate & 2 \\
\hline
\end{tabular}

As can be construed from Table (3), in the context of (med pharma), the mean score is 3.84 for Work-life balance which means that Work-life balance is applied to a great degree. In other words, Work-life balance is important, and the high value obtained demonstrates a positive attitude of respondents towards Work-life balance. Meanwhile, Happiness at work and Employee Performance appear to obtain judicious value, demonstrating the current engagement of (med pharma) with activities of Happiness at work and concentration on Employee Performance in order that superior performance could be maintained.

\subsection{Multicollinearity}

Multicollinearity relates to the level to which the independent variables employed in a multiple regression analysis have correlation (Ramadan et al., 2017). Multicollinearity causes the capacity in assessing the specific significance of each independent variable. When there are high levels of multicollinearity, the likelihood that a good predictor of the outcome will be deemed as non-significant and rejected from the model is increased (Hair et al., 2010).

The evaluation of multicollinearity employs indicators of Variance Inflation Factor (VIF) and tolerance. In this regard, a common cut-off value of 0.10 for acceptance, and a value of 10 for VIF were used to determine whether the present study has multicollinearity issue. These values have been proposed in the work of Sekaran and Bougie (2013).

The values of VIF for the independent variables that this study employs are highlighted in Table (4) and as shown, the values fall within the range of $1.076-1.465$, also, to the tolerance values which ranged from 0.697 
-0.836. As can be construed by these results, the dimensions of the independent variable show no multicollinearity issue which is evidenced by all the VIF values being lower than 10 while all values of tolerance are greater than 0.10 .

Table 4. The VIF and Tolerance Values for the Independent Variable

\begin{tabular}{ccc}
\hline Variables & Skewness & VIF \\
\hline Work-life balance & 0.714 & 1.465 \\
Employee engagement, & 0.761 & 1.237 \\
Job satisfaction, & 0.697 & 1.564 \\
Affective organizational commitment & 0.836 & 1.076 \\
\hline
\end{tabular}

\subsection{Hypotheses Testing Results}

The effect of Work-life balance and Happiness at work (employee engagement, job satisfaction, and affective organizational commitment) on Employee Performance in (Med pharma) is the focal point of this study. Hence, the techniques of multiple regression were used in the study to test the established hypotheses.

\section{Hypothesis 1}

H1: There is a statistically significant impact of Work-life balance on employee performance.

The outcomes of the test of hypothesis can be viewed in Table (5).

Table 5. Multiple Regression of the First Hypothesis

\begin{tabular}{llllllll}
\hline Variable & $\mathbf{R}$ & $\mathbf{R}^{2}$ & F-value & Sig (f) & B & T & Sig (t) \\
\hline Work-life balance & 0.652 & 0.573 & 42.243 a & $\mathbf{0 . 0 0 0 a}$ & 0.356 & 2.579 & $\mathbf{0 . 0 0 0}$ \\
\hline
\end{tabular}

Note. the impact is statistically significant at level $(\alpha \leq 0.05)$

Predictors: (Constant), Work-life balance b. Dependent variable: employee performance

Table (5) presents the results on the impact of the independent variables on the dependent variable (human capital) and the impact is statistically significant. Here, the computed F was $(42,243)$, at level (sig F= 0.000) and this value is lower than $(0.05)$. Further, the correlation coefficient $(\mathrm{R}=0.652)$ is showing a positive linkage between the variables, whereas the coefficient of determination was $\left(\mathrm{R}^{2}=0.573\right)$ which implies $57.3 \%$ of the change in attaining employee performance being explainable via the change within the Work-life balance. Table 5.Multiple Regression of the First Hypothesis

Table 6. Multiple Regression of the second Hypothesis

\begin{tabular}{|c|c|c|c|c|c|c|c|}
\hline Variable & $\mathbf{R}$ & $\mathbf{R}^{2}$ & F-value & Sig (f) & $\boldsymbol{\beta}$ & $\mathbf{T}$ & Sig (t) \\
\hline employee engagement & 0.459 & 0.408 & 42.36 & $0.000 a$ & 0.214 & 4.35 & 0.000 \\
\hline job satisfaction, & & & & & 0.127 & 2.79 & 0.056 \\
\hline $\begin{array}{c}\text { affective organizational } \\
\text { commitment }\end{array}$ & & & & & 0.415 & 6.45 & 0.000 \\
\hline
\end{tabular}

Note. The impact is statistically significant at level $(\alpha \leq 0.05)$

Predictors: (Constant), employee engagement, job satisfaction and affective organizational commitment

b. Dependent variable: employee performance

As Table (6) is showing, a positive correlation exists between Happiness at work and employee performance in Med Pharma, $(r=0.4599)$. This denotes the change of the independent variables and dependent variable in direction that is similar. The table shows $\mathrm{R} 2$ value which reflects the ratio of variation in employee performance explainable using the three variables of Happiness at work, implying $40.8 \%$ of employee performance variability being elucidated by the Happiness at work variables. In this regard, the data's F-value was 42.36 which demonstrates significance at $\mathrm{p}<0.05(\mathrm{sig}=0.000)$. As such, there exists statistically significance of the effect of Happiness at work variable on employee performance. The alternative hypothesis is therefore accepted. In particular, employee engagement scores a ( $t$ ) value of (4.35) with (0.000) level of significance, while job satisfaction scores a(t) value (2.79) with (0.056) level of significance for job satisfaction, whereby affective organizational commitment scores a ( $t)$ value of (6.45) with (0.000) level of significance. In terms of $\beta$ value for the three variables, it was $0.214,0.127$, and 0.415 respectively. Hence, for employee performance, affective organizational commitment can be said to be the highest predictor. This is followed by the variables of employee engagement and job satisfaction non-impact in employee performance. This study finds that Happiness at work (employee engagement, job satisfaction, affective organizational commitment) also has effect on employee performance. Specifically, this variable obtained $\mathrm{R} 2=0.408$ implying that $40.8 \%$ of the variation in employee performance is explainable by the three variables of Happiness at work. As can be observed from the obtained scores, the highest effect on employee performance came from the variable of affective organizational 
commitment. Affective organizational commitment encompasses a formal social network method encompassing direct knowledge and experience exchange amongst employees.

\section{Discussion}

This study explored the impact of Work-life balance and Happiness at work (employee engagement, job satisfaction, and affective organizational commitment) on employee performance among Med Pharma company. As the results are demonstrating, Work-life balance has a positive significant impact on employee performance, and this finding was also reported in the work of Helmle et al. (2014). In particular, Helmle et al. (2014) reported the impact of employee feeling comfortable (both physical and mental) on organizational success and its importance. As highlighted in the practical findings, employees with good feeling and only small degree of stress at work and at home show more likelihood to experience satisfaction with their work. The results are also showing that individuals who feel that there is interference of work roles with family roles show less likelihood to feel that they possess work-life balance. This finding is in line with the deduction made in Soomro et al. (2018) that work-life balance positively and significantly impacts employee performance.

Young employees with the capacity to find appropriate balance between work and family commitments appear to be the productive ones. Accordingly, organizations that offer adequate opportunities to their employees in managing their work and family roles will in turn reap the benefit from their employees showing stronger level of performance. Having a healthy work-life balance facilitates employees in performing her/his consigned tasks in more effective and efficient manner. Similar finding was also reported in Richert-Kaźmierska and Stankiewicz, (2016) where the authors warned the possible occurrence of unacceptable increase of staff turnover, especially among those with more talent and other career opportunities, due to failure in addressing work and life elements. The authors further mentioned the importance of the application of strong and applicable training programs, the provision of opportunities for promotion, and managers' genuine interest towards the well-being of employees' family and personal lives as among the ways in order to keep the staff contented. As mentioned earlier, in the context of Med Pharma, $40.8 \%$ of the variation in employee performance is explainable by the three variables of Happiness at work. Happiness at work (employee engagement, job satisfaction, affective organizational commitment) and the greatest impact on employee performance was from the affective organizational commitment. Hence, it can be concluded that staffs at Med Pharma have the complete understanding regarding the importance of committing to their organization.

Relevantly, a study Al-dalahmeh et al., (2018) has concluded that employee engagement within the workplace assists employees to survive as well as succeed when dealing with adverse situations, and this can also stimulate creativity among these employees. Expressed in another way, with the desire to discover fresh information to explore and integrate this new information, and then develop their own aptitude, employees are pushed to become creative.

In this study, job satisfaction appears to have no impact on employee performance, which contradicts with the past studies (Pawirosumaro et al., 2017, Semedo et al., 2017), which reported that job satisfaction had a significant positive effect on performance. Hence, taking steps to improve employee satisfaction can improve the general success of the organization. As a result, employees feel happier while demonstrating better workforce productivity with less workdays and greater level of profits. In agreement with this study, another study (Swalhi et al., 2017) that examined the effect of organizational commitment on employee performance reported the role of affective commitment being the first relationship signal in social interchange occurring between employees and their organization.

\section{Implications}

This study was established from the applicable past work. Accordingly, a research model is presented to investigate the impact of Work-life balance and Happiness at work on the performance of employee. As the extant literature is showing, there had been lack of studies on the subject in the context of Pharmaceutical industries. Hence, aside from being an expansion to the theoretical development, this study is of value to management of Pharmaceutical industries in the development and implementation of practices for the improvement of employee performance.

As can be deduced from this study's managerial implications, several recommendations can be derived for the perusal of managers of organizations, particularly those in Jordanian Pharmaceutical industries in order to encourage Work-life balance and Happiness at work as these will consequently improve employee performance of employees. Accordingly, more attention should be given to life quality elements which are known to impact performance. These elements are employee engagement, job satisfaction, and affective organizational commitment. 
The social relationship existing between the employees and their bosses and peers via the involvement in the training programs, the flexible system of working hours, enables different start and finish times. This way, employees could decide what is most appropriate for his or her family situation and have sufficient breaks during work. Other issues including maternity leave and childcare, husband care, and parental care can be satisfactorily dealt with. For managers, it is crucial that they address the needs of the employees as this consequently leads to the increase in the employees' involvement, and this will eventually increase organizational commitment. Hence, practices of human resource that will increase job involvement and job satisfaction levels among employees must be implemented.

\section{Limitations and Future Research Directions}

There are a number of limitations that this study needs to highlight in order that the validity of future research findings could be increased. First and foremost, this study was conducted within a very limited time frame which imposed restriction on the number of questionnaires distributed. Hence, if future study could be executed within longer time period, more questionnaires could be distributed which means that sample size would be bigger, and hence, increasing the generalizability of the study outcomes to the population. Also, since the focal point of this study was Pharmaceutical industries only, other organization were neglected. Hence, future study could be conducted in other types of organizations as to enrich the body of knowledge more.

The third limitation of this study is its usage of a quantitative technique as the primary method of data gathering and analyses, and this may limit the outcomes in terms of accuracy. Hence, future work could employ other techniques such as case studies in order to increase the accuracy of the outcomes particularly with respect to the conjectured relationships

Finally, this study had chosen Pharmaceutical industries as the study population and the problem with this is the fact that Pharmaceutical industries differ in terms of business execution as opposed to other bodies. Hence, it is suggested that future work would look at other types of organization or industry in exploring organizational commitment as to improve generalizability.

\section{References}

Abdallah, A. B., Obeidat, B. Y., Aqqad, N. O., Al Janini, M. N. K., \& Dahiyat, S. E. (2017). An Integrated Model of Job Involvement, Job Satisfaction and Organizational Commitment: A Structural Analysis in Jordan's Banking Sector. Communications and Network, 9(1), 28-53. https://doi.org/10.4236/cn.2017.91002

Abualoush, S. H., Obeidat, A. M., Ali, A., Masa'deh, R., \& Al-Badi, A. (2018a). "The role of employees' empowerment as an intermediary variable between knowledge management and information systems on employees' performance". VINE Journal of Information and Knowledge Management Systems, 48(2), 217-237. https://doi.org/10.1108/VJIKMS-08-2017-0050

Abualoush, S., Bataineh, K., \& Alrowwad, A. (2018b). The role of knowledge management process and intellectual capital as intermediary variables between knowledge management infrastructure and organization performance. Interdisciplinary Journal of Information, Knowledge, and Management, 13, 279-309.

Abualoush, S., Khaled Bataineh, K., \& Aladwan, A. (2017). Impact of Information Systems on Innovation (Product Innovation, Process Innovation) - Field Study on the Housing Bank in Jordon. International Journal of Business Administration, 8(1), 95-105. https://doi.org/10.5430/ijba.v8n1p95

Al-dalahmeh, M., Masa'deh, R., Abu Khalaf, R. K., \& Obeidat, B. Y. (2018). The Effect of Employee Engagement on Organizational Performance via the Mediating Role of Job Satisfaction: The Case of IT Employees in Jordanian Banking Sector. Modern Applied Science, 12(6), 17-43. https://doi.org/10.5539/mas.v12n6p17

Ammari, G., Al Kurdi. B., Alshurideh, M., Obeidat, B. Y., Abu Hussien, A., \& Alrowwad, A. (2017). Investigating the Impact of Communication Satisfaction on Organizational Commitment: A Practical Approach to Increase Employees' Loyalty. International Journal of Marketing Studies, 9(2), 113-133. https://doi.org/10.5539/ijms.v9n2p113

Anitha, J. (2014). Determinants of employee engagement and their impact on employee performance. International Journal of Productivity and Performance Management, 63(3), 308-323. https://doi.org/10.1108/IJPPM-01-2013-0008

Anwar, J., Hansu, S. A. F., \& Janjua, S. Y. (2013). Work-life balance: What organizations should do to create balance? World Applied Sciences Journal, 24(10), 1348-1354 
Au, W. C., \& Ahmed, P. K. (2014)."Sustainable people management through work-life balance: a study of the Malaysian Chinese context". Asia-Pacific Journal of Business Administration, 6(3), 262-280. https://doi.org/10.1108/APJBA-02-2014-0024

Bagozzi, R., \& Yi, Y. (1988). On the evaluation of structural evaluation models. Journal of the Academy of Marketing Science, 16(1), 74-94. https://doi.org/10.1007/BF02723327

Bisharat, H., Obeidat, B. Y., Alrowwad, A., Tarhini, A., \& Mukattash, I. (2017). eEffect of Human Resource Management Practices on Organizational Commitment in Chain Pharmacies in Jordan. International Journal of Business and Management, 12(1), 50-67. https://doi.org/10.5539/ijbm.v12n1p50

Breitenecker, R. J., \& Shah, S. A. M. (2018). Relation of work-life balance, work-family conflict, and family-work conflict with the employee performance-moderating role of job satisfaction. South Asian Journal of Business Studies, 7(1), 129-146. https://doi.org/10.1108/SAJBS-02-2017-0018

Edmunds, L. D., \& Pryce-Jones, J. (2008). Relationships between happiness, overtime, sick leave and intention to stay or leave. Selection \& Development Review, 24, 8-12.

Emslie, C., \& Hunt, K. (2009). "Live to work or work to live?". The Australian and New Zealand Journal of Organizational Psychology, 3, 54-65.

Enache, M., Sallan, J. M., Simo, P., \& Fernandez, V. (2013). Organizational Commitment within a Contemporary Career Context. International Journal of Manpower, 34, 880-898. https://doi.org/10.1108/IJM-07-2013-0174

Faiza, T. A., \& Nazir, F. S. (2015). Capacity building boost employees performance. Industrial and Commercial Training, 47(2), 61-66. https://doi.org/10.1108/ICT-05-2014-0036

Field, L. K., \& Buitendach, J. H. (2011). Happiness, work engagement and organisational commitment of support staff at a tertiary education institution in South Africa. SA Journal of Industrial Psychology/SA Tydskrif vir Bedryfsielkunde, 37(1), 1-10. https://doi.org/10.4102/sajip.v37i1.946

Fisher, D. C. (2010). Happiness at Work. The International Journal of Management Reviews, 12(4), 384-412. https://doi.org/10.1111/j.1468-2370.2009.00270.x

Greenhaus, G. H., \& Allen, T. D. (2010). "Work-family balance: a review and extension of the literature", in Tetrick, L. and Quick, J.C. (Eds), Handbook of Occupational Health Psychology, 2nd ed., American Psychological Association, Washington, DC, pp. 165-183.

Grzywacz, J. G., \& Carlson, D. S. (2007). Conceptualizing work-family balance: implications for practice and research. Advances in Developing Human Resources, 9(4), 455-471. https://doi.org/10.1177/1523422307305487

Gupta, V. (2012). Importance of Being Happy at Work. International Journal of Research and Development - A Management Review, 1(1), 9-14.

Guthrie, V. M. J. (2012). "Management control of work-life balance. A narrative study of an Australian financial institution". Journal of Human Resource Costing \& Accounting, 16(4), 258-280. https://doi.org/10.1108/14013381211317248

Gyensare, M. A., Kumedzro, L. E., Sanda, A., \& Boso, N. (2017). "Linking transformational leadership to turnover intention in the public sector: The influences of engagement, affective commitment and psychological climate". African Journal of Economic and Management Studies, 8(3), 314-337. https://doi.org/10.1108/AJEMS-07-2016-0099

Hair, J., Black, W., Babin, B., \& Anderson, R. (2010). Multivariate data analysis. Prentice Hall, Inc., Upper Saddle River, NJ.

Helmle, J. R., Botero, I. C., \& Seibold, D. R. (2014). "Factors that influence perceptions of work-life balance in owners of copreneurial firms". Journal of Family Business Management, 4(2), 110-132. https://doi.org/10.1108/JFBM-06-2014-0013

Hon, A., \& Chan, W. (2013). "The effects of group conflict and work stress on employee performance". Cornell Hospitality Quarterly, 54(2), 174-184. https://doi.org/10.1177/1938965513476367

Huang, L. C., Ahlstrom, D., Lee, A. Y. P., Chen, S. Y., \& Hsieh, M. J. (2016). "High performance work systems, employee well-being, and job involvement: an empirical study". Personnel Review, 45(2), 296-314. https://doi.org/10.1108/PR-09-2014-0201 
Johari, J., Yean Tan, F., \& Tjik Zulkarnain, Z. I. (2018). Autonomy, workload, work-life balance and job performance among teachers. International Journal of Educational Management, 32(1), 107-120. https://doi.org/10.1108/IJEM-10-2016-0226

Joo, B. K., \& Lee, I. (2017). "Workplace happiness: work engagement, career satisfaction, and subjective well-being", Evidence-based HRM. A Global Forum for Empirical Scholarship, 5(2), 206-221. https://doi.org/10.1108/EBHRM-04-2015-0011

Koubova, V., \& Buchko, A. A. (2013). "Life-work balance: Emotional intelligence as a crucial component of achieving both personal life and work performance". Management Research Review, 36(7), 700-719. https://doi.org/10.1108/MRR-05-2012-0115

Lavoie, M. (2004). "Post Keynesian consumer theory: potential synergies with consumer research and economic psychology". Journal of Economic Psychology, 25(5), 639-649. https://doi.org/10.1016/j.joep.2003.02.001

Lawson, K. M., Davis, K. D., Crouter, A. C., \& O'Neill, J. W. (2013). “Understanding work-family spillover in hotel managers". International Journal of Hospitality Management, 33, 273-281. https://doi.org/10.1016/j.ijhm.2012.09.003

López-Cabarcos, M. A., de Pinho, A. I. M. S., \& Vázquez-Rodríguez, P. (2015). "Organizational justice and personal initiative, mediating role of affective commitment". Journal of Service Theory and Practice, 25(6), 854-876. https://doi.org/10.1108/JSTP-09-2014-0218

Masa'deh, R., Alrowwad, A., Alkhalafat, F., Obeidat, O., \& Abualoush, S. (2018). The role of corporate social responsibility in enhancing firm performance from the perspective of IT employees in Jordanian banking sector: The mediating effect of transformational leadership. Modern Applied Science, 12(7), 1-26. https://doi.org/10.5539/mas.v12n7p1

Mullen, J., \& Kelloway, E. K. (2010). "Occupational health and safety leadership", in Quick, J.C. and Tetrick, L.E. (Eds), Handbook of Occupational Health Psychology, 2nd ed., American Psychological Association, Washington, DC.

Nielsen, K., Randall, R., Yarker, J., \& Brenner, S. O. (2008). "The effects of transformational leadership on followers' perceived work characteristics and psychological well-being: a longitudinal study". Work \& Stress, 22(1), 16-32. https://doi.org/10.1080/02678370801979430

Obeidat, A. M., Abualoush, S., Irtaimeh, H., Khaddam, A. A., \& Bataineh, K. (2018), The role of organizational culture in enhancing the human capital applied study on the social security corporation. International Journal of Learning and Intellectual capital, 15(3), 258-276. https://doi.org/10.1504/IJLIC.2018.094718

Obeidat, B. Y., Masa'deh, R. M., \& Abdallah, A. B. (2014). The Relationships among Human Resource Management Practices, Organizational Commitment, and Knowledge Management Processes: A Structural Equation Modeling Approach. International Journal of Business and Management, 9(3), 9-26. https://doi.org/10.5539/ijbm.v9n3p9

Parvin, M. M., \& Kabir, M. M. N. (2011). Factors affecting employee job satisfaction of pharmaceutical sector. Australian Journal of Business and Management Research, 1(9), 113-123.

Pawirosumaro, S., Sarjana, P. K., \& Gunawan, R. (2017). "The effect of work environment, leadership style, and organizational culture towards job satisfaction and its implication towards employee performance in Parador Hotels and Resorts, Indonesia". International Journal of Law and Management, 59(6), 1337-1358. https://doi.org/10.1108/IJLMA-10-2016-0085

Pawirosumarto, S., Sarjana, P. K., \& Muchtar, M. (2017). "Factors Affecting Employee Performance of PT. Kiyokuni Indonesia". International Journal of Law and Management, 59(4), 203-221. https://doi.org/10.1108/IJLMA-03-2016-0031

Ramadan, B., Dahiyat, S., Bontis, N., \& Al-dalahmeh, M. (2017). Intellectual Capital, Knowledge Management and Social Capital within the ICT Sector in Jordan. Journal of Intellectual Capital, 18(2), 437-462. https://doi.org/10.1108/JIC-06-2016-0067

Richert-Kaźmierska, A., \& Stankiewicz, K. (2016). Work-life balance: Does age matter? IOS Press, 55, 679-688.

Saenghiran, N. (2014). Towards enhancing happiness at work: a case study. Social Research Reports, 25, 21-33.

Salas-Vallina, A., López-Cabrales, A., Alegre, J., \& Fernández, R. (2017) "On the road to happiness at work (HAW): Transformational leadership and organizational learning capability as drivers of HAW in a 
healthcare context". Personnel Review, 46(2), 314-338. https://doi.org/10.1108/PR-06-2015-0186

Schaufeli, W. B., \& Bakker, A. B. (2004). "Job demands, job resources, and their relationship with burnout and engagement: a multi-sample study". Journal of Organizational Behavior, 25(3), 293-315. https://doi.org/10.1002/job.248

Schoemmel, K., \& Jønsson, T. S. (2014). "Multiple affective commitments: quitting intentions and job performance". Employee Relations, 36(5), 516-534. https://doi.org/10.1108/ER-08-2013-0116

Sekaran, U., \& Bougie, R. (2013). Research Methods for Business (6th ed). United Kingdom: John Wiley \& Sons Ltd.

Semedo, A. S. D., Coelho, A. F. M., \& Ribeiro, N. M. P. (2017). "Authentic leadership and creativity: the mediating role of happiness". International Journal of Organizational Analysis, 25(3), 395-412. https://doi.org/10.1108/IJOA-03-2016-0994

Semlali, S., \& Hassi, A. (2016). "Work-life balance: how can we help women IT professionals in Morocco?". Journal of Global Responsibility, 7(2), 210-225. https://doi.org/10.1108/JGR-07-2016-0017

Shaffer, M. A., Reiche, B. S., Dimitrova, M., Lazarova, M., Chen, S., Westman, M., \& Wurtz, O. (2016). "Work and family role adjustment of different types of global professionals: Scale development and validation". Journal of International Business studies, 47(2), 113-139. https://doi.org/10.1057/jibs.2015.26

Soomro, A. A., Breitenecker, R. J., \& Shah, S. A. M. (2018). "Relation of work-life balance, work-family conflict, and family-work conflict with the employee performance-moderating role of job satisfaction". South Asian Journal of Business Studies, 7(1), 129-146. https://doi.org/10.1108/SAJBS-02-2017-0018

Susana, P., \& Ramón, V. C. (2013). "Work-life balance under challenging financial and economic conditions". International Journal of Manpower, 34(8), 961-974. https://doi.org/10.1108/IJM-07-2013-0172

Swalhi, A., Zgoulli, S., \& Hofaidhllaoui, M. (2017). "The influence of organizational justice on job performance: The mediating effect of affective commitment". Journal of Management Development, 36(4), 542-559. https://doi.org/10.1108/JMD-11-2015-0162

Vincent-Höper, S., Muser, C., \& Janneck, M. (2012). "Transformational leadership, work engagement, and occupational success". Career Development International, 17(7), 663-682. https://doi.org/10.1108/13620431211283805

Yücel, I. (2012). Examining the Relationships among Job Satisfaction, Organizational Commitment, and Turnover Intention: An Empirical Study. International Journal of Business and Management, 7, 44-58. https://doi.org/10.5539/ijbm.v7n20p44

\section{Copyrights}

Copyright for this article is retained by the author(s), with first publication rights granted to the journal.

This is an open-access article distributed under the terms and conditions of the Creative Commons Attribution license (http://creativecommons.org/licenses/by/4.0/). 